Jurnal Hukum Mimbar Justitia

Fakultas Hukum Universitas Suryakancana

Vol. 3 No. 2 - Desember 2017 p. 137-156

ISSN: 2477-5681 (Cetak), ISSN: 2580-0906 (Online)

Open Access at: https://jurnal.unsur.ac.id/jmj

\title{
DINAMIKA PEMBAYARAN UANG PENGGANTI DALAM TINDAK PIDANA KORUPSI
}

\author{
Ade Mahmud \\ Program Studi Hukum \\ Fakultas Ilmu Sosial dan Politik Universitas Jenderal Achmad Yani \\ E-mail: ademahmud86@yahoo.com
}

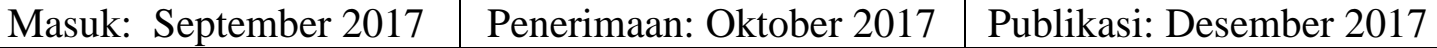

\begin{abstract}
ABSTRAK
Pelaksanaan pidana uang pengganti dalam perkara tindak pidana korupsi menimbulkan dinamika yang cukup pelik karena dibenturkan dengan aturan normatif yang memberikan celah terpidana untuk menjalani pidana subsider. Hasil penelitian menunjukan (1) Pelaksanaan pembayaran pidana uang pengganti mengalami dinamika yang kompleksitas karena aturan pidana tambahan dalam Undang-Undang Nomor 31 Tahun 1999 Tentang Pemberantasan Tindak Pidana Korupsi memberikan ruang bagi hakim untuk mensubsiderkan pidana uang pengganti dengan pidana penjara yang relatif singkat. Realitas empiris menunjukan terjadi kecenderungan terpidana korupsi untuk memilih menjalani pidana subsider dibandingkan membayar uang pengganti karena bobot pidana subsider jauh lebih ringan dan cukup ekonomis daripada harus mengganti kerugian negara sehingga negara secara ekonomi tetap merugi dan indeks persepsi korupsi terus mengalami peningkatan. (2) Strategi penegakan hukum pidana untuk mengatasi dinamika pidana uang pengganti adalah menerapkan konsep hukum progresif yang setia pada asas besar "hukum untuk manusia" Konkritisasi hukum progresif dalam strategi mengatasi problem uang pengganti dilaksanakan dengan melakukan upaya terobosan hukum (rule breaking) berupa sita jaminan terhadap aset milik pelaku tanpa melihat status aset berkaitan atau tidak dengan tindak pidana korupsi. Upaya sita jaminan dilakukan semata-mata hanya untuk mengantisipasi agar harta yang akan menjadi obyek uang pengganti tidak beralih kepada pihak lain dan memudahkan jaksa untuk melakukan eksekusi manakala hakim menjatuhkan pidana uang pengganti kepada terdakwa.
\end{abstract}

Kata Kunci: Dinamika Pidana Uang Pengganti; Korupsi; Pidana Subsider; Terobosan Hukum (Rule Breaking).

\section{ABSTRACT}

The implementation of criminal money subtitution in criminal act of corruption pose dynamic is quite complicated because it crashed with the rules normative that provide a gap of the convicted person to undergo criminal subsidiary.The result showed (1) the implementation of the payment of a criminal restitution experience the dynamic of a spectrum of complexity because the rule of criminal additions in the law No 31 year 1999 on eradication of Coruption provide a space for the judge to subsidiary criminal money subtitute to imprisonment is relatively short. The empirical reality shows there is 
a tendency convicted of corruption choose undergo a criminal subsider than pay the money subtitute because od the weight criminal subsider munch lighter and quite economical than having to replace the losses to the state so that the state int the economy remains loss and corruption perception index remained elevated. Strategy the enforcement of the criminal law to cope with the dynamics of criminal is to apply the concept of the law progresif loyal to the great principles of the law to human . Konritization progressive law in addressing the problem of money subtitute implemented by a breakthrough law in the reform of foreclosur. guarantee againts the assets belonging to the offender without looking at the status of the asset associated or not with corruption. The effort of foreclosure guarantee best done just solely to anticipate that the treasure will be easy money subtitute not switch to another party and facilitate the attorney to reform the execution when the judge dropped money subtitute ti the defendant.

Keywords: Criminal Dynamics of Replacement Cash; Corruption; Subsidiary Criminal; Rule Breaking.

\section{PENDAHULUAN}

Dalam majalah Der Spegel Edisi Juli 1995 dan Majalah Fortune Edisi Agustus 1995, tingkat kerawanan tindak pidana korupsi di Indonesia mendapat peringkat terburuk hampir sama dengan korupsi di Republik Rakyat Cina (RRC). Transparency International (TI) dalam penelitiannya di tahun 19982003, menempatkan Indonesia pada posisi 10 besar negara paling korupsi di dunia. Demikian pula Political Economy Risk Consultancy (PERC) dalam penelitiannya tahun 1997 mengemukakan bahwa Indonesia menempati posisi negar yang terkorup di Asia, dan pada tahun 2001 Indonesia turun peringkat menjadi negara terkorup kedua di Asia setelah Vietnam. ${ }^{1}$ Transparancy Internasiotional mengeluarkan tinjauan terbaru mengenai negara paling korup di planet bumi. Dalam data Indeks persepsi korupsi 2016, Indonesia masih berada di peringkat 90 dari 176 negara dengan skor $37 .^{2}$

Tingginya angka korupsi di Indonesia salah satunya disebabkan oleh sanksi pidana yang cenderung ringan baik pidana penjara maupun pidana denda atau pidana uang pengganti. Kebijakan penal pemberantasan korupsi tidak memberikan efek jera yang

1 Chaerudin dkk, Strategi Pencegahan dan Penegakan Hukum Tindak Pidana Korupsi, Refika Aditama, Bandung, 2008, hlm. v.

2 Eva Mazrieva, Indeks Perspesi Korupsi Indonesia htts//voaindonesia.com. diakses Tgl 25 Oktober 2017, Pkl. 13.00. 
mampu mencegah terjadinya tindak pidana korupsi. Kebijakan penalisasi tambahan berupa penutupan perusahaan dan pembayaran uang pengganti dalam Undang-Undang Nomor 31 Tahun 1999 Tentang Pemberantasan Tindak Pidana Korupsi belum mampu menunjukan fungsinya untuk menurunkan Indeks persepsi korupsi Indonesia di mata dunia.

Tantangan bagi aparat penegak hukum adalah bagaimana hukuman yang diberikan membuat para koruptor jera sekaligus membuat yang lain takut untuk melakukan korupsi. ${ }^{3}$ Untuk itu hukumannya bukan hanya sekedar pidana penjara, tetapi juga sanksi yang melahirkan rasa jera, malu, dan takut. Menimbulkan efek jera ini justru sangat penting untuk memperkecil angka korupsi di Indonesia dari tahun ke tahun. ${ }^{4}$ Hal itu semestinya mampu diciptakan oleh para penegak hukum melalui berbagai sanksi pidana yang ada untuk menanggulangi tindak pidana korupsi.

3 Iswan Kaputra dkk, Dampak Otonomi Daerah di Indonesia, Yayasan Obor Indonesia, Jakarta, 2013, hlm. 53.

4 Yesmil Anwar, Pembaharuan Hukum Pidana, PT Gramedia Widiasarana Indonesia, Jakarta, 2008, hlm. 270.
Dalam hukum positif pidana uang pengganti telah diatur dalam Pasal 18 ayat (1) huruf b Undang-Undang Nomor 31 Tahun 1999 Tentang Pemberantasan Tindak Pidana Korupsi bahwa "Pembayaran uang pengganti yang jumlahnya sebanyak-banyaknya dengan harta benda yang diperoleh dari tindak pidana korupsi". Aturan ini dikaji dari segi kebijakan politik hukum pemberantasan korupsi adalah sebuah kemajuan karena menunjukan adanya kemauan negara untuk mengembalikan uang negara yang hilang/berkurang akibat tindak pidana korupsi. Tetapi Pasal 18 ayat (3) menyebutkan bahwa:

Dalam hal terpidana tidak mempunyai harta benda yang mencukupi untuk membayar uang pengganti sebagaimana dimaksud dalam ayat (1) huruf b, maka dipidana dengan pidana penjara yang lamanya tidak melebihi ancaman maksimum dari pidana pokoknya sesuai ketentuan dalam undang-undang ini dan lamanya pidana tersebut sudah ditentukan dalam putusan pengadilan.

Aturan ini menimbulkan problem yuridis karena satu sisi memiliki semangat pemulihan aset melalui kebijakan uang pengganti tetapi di 
Ade Mahmud

Jurnal Hukum Mimbar Justitia

Vol. 3 No. 2 - Desember 2017

pihak lain memberikan peluang bagi terpidana untuk memilih membayar uang pengganti atau menjalani pidana subsider. ${ }^{5}$ Secara kebijakan politik hukum pidana aturan ini dapat dimaklumi sebagai aturan yang bersifat alternatif untuk mengantisipasi apabila terpidana benar-benar tidak memiliki harta yang cukup untuk membayar uang pengganti. Akan tetapi realitas empiris menunjukan aturan ini telah dimanfaatkan para koruptor untuk menghindari pidana uang pengganti, karena ketika dijatuhi pidana tambahan berupa pembayaran uang pengganti mereka mengaku tidak memiliki harta untuk melunasi uang pengganti. Akibatnya jaksa harus mengkonversi (subsider) uang penganti dengan pidana penjara yang bobotnya telah ditentukan dalam putusan pengadilan. ${ }^{6}$ Putusan

5 Fontian Munzil, dkk, Kesebandingan Pidana Uang Pengganti dan Pengganti Pidana Uang Pengganti Dalam Rangka Melindungi Hak Ekonomi Negara dan Kepastian Hukum, Jurnal Hukum Ius Quia Iustum, Vol. 22, No. 1, Januari 2015, hlm. 42.

6 Dalam Pasal 18 ayat (3) Undang-Undang Nomor 31 Tahun 1999 tentang Pemberantasan Tindak Pidana Korupsi, pidana pembayaran uang pengganti dimungkinkan dapat diganti dengan pidana penjara pengganti apabila terpidana korupsi tidak memiliki harta yang mencukupi untuk membayar pidana pembayaran uang pengganti. Ketentuan ini menjadi celah hukum bagi para koruptor untuk pengadilan demikian tidak mungkin mampu mengembalikan kerugian negara akibat tindak pidana korupsi dan tidak akan menimbulkan efek jera.

Problem ini menjadi dinamika proses yudisial terutama pada saat pelaksanaan eksekusi pidana uang pengganti. Negara menyimpan harapan besar kembalinya uang negara dengan membuat regulasi pemulihan aset akibat tindak pidana korupsi melalui aturan pidana tambahan dalam UndangUndang Nomor 31 Tahun 1999 Jo Undang-Undang Nomor 20 Tahun 2000 Tentang Pemberantasan Tindak Pidana Korupsi tetapi dalam kenyataan aturan normatif justru memberikan kelonggaran terhadap pelaku untuk lolos dari kewajiban membayar uang pengganti dan tetap bisa menikmati hasil tindak pidana korupsi.

Menurut data Litbang Komisi Pemberantasan Korupsi (KPK) nilai kerugian negara akibat tindak pidana

meloloskan diri dari kewajiban mengganti kerugian keuangan negara akibat korupsi melalui pidana uang pengganti dengan mengatakan/mengakui bahwa dirinya tidak memiliki harta yang cukup untuk mengembalikan kerugian negara sehingga secara otomatis pidana uang pengganti digantikan dengan pidana penjara pengganti sebagaimana diatur dalam Pasal 18 ayat (3) Undang-undang Korupsi. 
korupsi di Indonesia selama 2003-2015 mencapai Rp 153,01 triliun (seratus lima puluh tiga koma satu triliun). Sedangkan jumlah hukuman finansial yang berhasil mengembalikan kerugian negara berupa denda, penyitaan aset dan pembayaran uang pengganti hanya terkumpul $\mathrm{Rp}$ 15.957.821.529.773.(lima belas triliun lebih), atau sekitar 10,4\%. Total kerugian negara itu berasal dari 2.321 kasus yang melibatkan 3.109 terdakwa. Data ini menunjukan bahwa hukuman finansial kepada para terpidana korupsi cenderung suboptimal, lebih rendah dari kerugian negara yang muncul akibat korupsi. ${ }^{7}$ Aturan pidana tambahan berupa pembayaran uang pengganti belum cukup efektif mengembalikan uang negara yang hilang/berkurang akibat tindak pidana korupsi. Identifikasi masalah dalam penelitian ini yaitu: 1. Bagaimana dinamika pembayaran pidana uang pengganti akibat tindak pidana korupsi dalam upaya pemulihan aset?; 2. Bagaimana strategi penegakan hukum pidana untuk mengatasi dinamika pidana uang pengganti?.

7 Marwan Mas, Pemberantasan Tindak Pidana Korupsi, Ghalia Indonesia, Bogor, 2015, hlm. 146.

\section{METODE PENELITIAN}

Penelitian ini menggunakan pendekatan hukum normatif (yuridis normatif) karena akan mengkaji norma dan asas dalam Undang-Undang Nomor 31 Tahun 1999 Jo Undang-Undang Nomor 20 Tahun 2001 tentang Pemberantasan Tindak Pidana Korupsi dengan cara menggunakan data sekunder yang berkaitan dengan pelaksanaan pidana pembayaran uang pengganti dalam perkara tindak pidana korupsi melalui penegakan hukum progresif.

Spesifikasi penelitian ini adalah deskriptif analitis karena akan menggambarkan suatu kenyataan dan fakta-fakta yang berkaitan dengan pidana pembayaran uang pengganti kemudian dianalisis dengan menggunakan berbagai teori dan peraturan yang berkaitan erat dengan permasalahan yang dikemukakan.

Jenis data yang digunakan dalam penelitian ini adalah data sekunder yang bersumber pada bahan hukum primer, sekunder dan tersier.

Teknik pengumpulan data menggunakan studi kepustakaan yakni menganalisis sumber bacaan yang bersifat teoritis ilmiah seperti buku- 
Ade Mahmud

Jurnal Hukum Mimbar Justitia

Vol. 3 No. 2 - Desember 2017

buku, jurnal ilmiah baik nasional maupun internasional, makalah yang telah diseminarkan sehingga dapat dijadikan dasar penelitian dalam menganalisis persoalan yang dikemukakan.

Metode analisis yang digunakan adalah kualitatif yaitu suatu cara penelitian yang menghasilkan data deskriptif analitis, karena tidak menggunakan rumus-rumus dan angkaangka dengan menggunakan metode berfikir deduktif. Metode deduktif ialah suatu cara berfikir yang berawal dari proposisi umum yang kebenaranya telah diketahui dan berakhir pada suatu pengetahuan baru yang khusus.

\section{HASIL PENELITIAN DAN} ANALISIS

A. Dinamika Pembayaran Pidana Uang Pengganti Akibat Tindak Pidana Korupsi Dalam Rangka Pemulihan Aset

Masalah pembayaran uang pengganti akibat tindak pidana korupsi merupakan persoalan yang tidak luput menjadi perhatian dalam upaya pemberantasan korupsi di era demokrasi sekarang ini. Kuatnya dorongan masyarakat untuk membebaskan diri dari kejahatan korupsi membuat pemerintah membentuk berbagai regulasi untuk mengembalikan kerugian keuangan negara akibat tindak pidana korupsi. Salah satunya merumuskan norma yang mewajibkan terpidana untuk membayar uang pengganti dalam Undang-undang 31 Tahun 1999 Jo Undang-Undang Nomor 20 Tahun 2001 Tentang Pemberantasan Korupsi.

Dalam Pasal 18 ayat (1) huruf b Undang-undang Pemberantasan Korupsi disebutkan bahwa "Pembayaran uang pengganti yang jumlahnya sebanyakbanyaknya harta benda yang diperoleh dari tindak pidana korupsi". Namun dalam Pasal 18 ayat (3) mencantumkan rumusan norma yang bersifat kompromistis bahwa:

"Dalam hal terpidana tidak mempunyai harta benda yang mencukupi untuk membayar uang pengganti sebagaimana dimaksud dalam ayat (1) huruf b, maka dipidana dengan pidana penjara yang lamanya tidak melebihi ancaman pidana maksimum dari pidana pokoknya sesuai dengan ketentuan dalam undang-undang ini dan karenanya pidana tersebut sudah ditentukan dalam putusan pengadilan".
8 Ketentuan ini dijadikan sebagai aturan yang bersifat kompromistis antara penegak hukum dengan terpidana, apabila dalam kondisi tertentu terpidana tidak memiliki 
Ketentuan ini secara faktual dimanfaatkan oleh terpidana kasus korupsi yang merugikan keuangan negara dalam jumlah besar, mereka menyembunyikan aset hasil korupsi dalam sistem keuangan bank maupun non bank yang sulit terlacak oleh PPATK agar terlihat seolah-olah mereka tidak menikmati hasil korupsi untuk menghindari kewajiban membayar uang pengganti dan menggantinya dengan pidana penjara. Alhasil meskipun penyidik dan penuntut umum mampu membuktikan unsur kerugian negara di persidangan, tetapi pada akhirnya hakim secara legalistikpositivistik akan memberikan kesempatan pada terpidana untuk memilih membayar uang pengganti atau menggantinya dengan pidana penjara.

Kondisi yang lebih memprihatinkan pidana penjara pengganti dijatuhkan hakim sebagai ganti dari pidana uang pengganti masih ada beberapa yang merujuk pada ketentuan Pasal 30 ayat (3) KUHP yang menentukan bahwa "lamanya pidana kurungan pengganti paling sedikit satu

harta benda yang mencukupi untuk membayar uang pengganti sebagai upaya menutupi kerugian keuangan negara akibat tindak pidana korupsi. hari dan paling lama enam bulan”. Ketentuan ini masih dirujuk oleh para hakim dalam menentukan pidana penjara pengganti bagi para koruptor yang tidak membayar uang pengganti. Dampaknya adalah pidana penjara pengganti lamanya berkisar 1 (satu) sampai 6 (enam) bulan, atau kalaupun lebih tinggi hanya sampai 1 (satu) tahun sampai 2 (dua) tahun. Dengan nilai kerugian negara mencapai puluhan dan ratusan miliar rupiah. ${ }^{9}$

Salah satu contoh putusan pengadilan No 119/Pid.B/2013.PN.Mdn menjatuhkan pidana kepada terdakwa Syarif Muda Hasibuan dengan pidana penjara 14 bulan dan denda $\mathrm{Rp}$ 50.000.000.- subsider 2 bulan penjara dan wajib membayar uang pengganti sebesar Rp 700.000.000,- dengan ketentuan apabila tidak dibayar maka harta bendanya dapat disita dan dilelang oleh jaksa, dan jika harta benda terdakwa tidak mencukupi untuk membayar uang pengganti maka dapat diganti dengan pidana penjara selama 6 (bulan). Hasilnya menunjukan pidana

9 Ade Paul Lukas, Efektivitas Pidana Pembayaran Uang Pegganti Dalam Tindak Pidana Korupsi, Jurnal Dinamika Hukum, Fakultas Hukum Universitas Jenderal Soedirman, Vol. 10, No. 2, Mei 2010, hlm. 184. 
uang pengganti tersebut tidak dibayar dan diganti dengan subsider 6 (enam) bulan. ${ }^{10}$

Contoh lain putusan pengadilan No 118/Pid.B/2007.PN.Pwt menjatuhkan pidana kepada terdakwa Ahmad Husen dengan pidana uang pengganti sebesar Rp 50.000.000,dengan ketentuan apabila tidak dibayar maka harta bendanya dapat disita dan dilelang oleh jaksa, dan jika harta benda terdakwa tidak mencukupi maka dapat diganti dengan pidana penjara selama 1 (bulan). Putusan ini prakteknya dijalankan serupa terpidana lebih memilih menjalani pidana subsider 1 (satu) bulan. ${ }^{11}$

Implementasi pembayaran uang pengganti untuk mengembalikan kerugian negara akibat korupsi mengalami dinamika yang cukup pelik, karena ketentuan dalam Pasal 18 ayat (3) Undang-Undang Nomor 31 Tahun 1999 Sebagaimana telah diubah dengan Undang-Undang Nomor 20 Tahun 2001 Tentang Pemberantasan Tindak Pidana Korupsi, memberi toleransi bahwa jika

10 Korupsi Dana Kesbangpol, Syarif Muda Dijatuhi Hukuman 14 bulan penjara. diakses tribunnews.com tgl 1 April 2015. Pkl 13.00

11 Warmanplaw.blogspot.co.id. diakses tgl 1 April 2015. Pkl. 14.00. terpidana tidak mempunyai harta benda yang mencukupi untuk membayar uang pengganti, maka dipidana (diganti) dengan pidana penjara yang lamanya tidak melebihi ancaman maksimum dari pidana pokoknya, dan pidana tersebut sudah ditentukan dalam putusan pengadilan.

Aturan pidana pengganti atas pembayaran uang pengganti kerugian negara yang tercantum dalam Pasal 18 ayat (3) Undang-Undang Nomor 31 Tahun 1999 sebagaimana telah diubah dengan Undang-Undang Nomor 20 Tahun 2001 Tentang Pemberantasan Tindak Pidana Korupsi menjadi akar permasalahan yang menjadi penghambat bagi jaksa eksekutor ketika melakukan eksekusi pembayaran uang pengganti untuk menutupi kerugian negara yang dibebankan kepada terpidana.

Pidana penjara pengganti (subsider) menjadi masalah pada saat jaksa akan melakukan eksekusi. Pidana pengganti menjadi peluang bagi para terpidana korupsi untuk menghindari pembayaran pidana uang pengganti. Para koruptor cenderung lebih banyak memilih menggantinya dengan pidana pengganti yang lamanya rata-rata 6 
(enam) bulan apabila merujuk pada

Pasal 30 KUHP. Pada akhirnya putusan pengadilan Tipikor yang menjatuhkan pembayaran pidana uang pengganti untuk mengembalikan kerugian negara menjadi sia-sia karena pidana penjara pengganti menjadi celah bagi para terpidana korupsi untuk mengamankan harta hasil korupsi. ${ }^{12}$

Pertimbangan yang dijadikan dasar koruptor memilih mengganti pidana uang pengganti cukup ekonomis mereka berfikir lebih baik mendekam dalam penjara selama waktu tertentu (cenderung singkat) daripada harus membayar uang pengganti yang jumlahnya cukup besar. Sebelum mengambil keputusan tersebut mereka sudah menyembunyikan aset hasil korupsi terlebih dahulu yang mereka simpan dan sulit dilacak oleh penegak hukum, sehingga tidak memungkinkan jaksa eksekutor untuk menyita dan melelangnya karena tidak

12 Menurut penulis praktek inilah yang bertentangan dengan asas asset recovery yang tercermin dalam Undang-undang Pemberantasan Tindak Pidana Korupsi. Padahal asas ini menghendaki dalam praktek penegakan hukum sejalan dengan maksud pembentuk undang-undang yakni menginginkan adanya asset recovery yang dilakukan oleh terpidana korupsi untuk digunakan demi kepentingan rakyat banyak. memungkinkan untuk mengganti kerugian negara. Artinya sekalipun koruptor telah berhasil ditangkap, diadili dan dipidana uang pengganti negara tetap saja merugi karena kerugian negara yang hilang tidak dapat dikembalikan secara utuh.

Dinamika penjatuhan pembayaran uang pengganti dalam rangka menyelesaikan keuangan negara pernah diungkapkan Ramelan adalah:

1. Kasus korupsi dapat terungkap setelah berjalan dalam kurun waktu yang lama sehingga sulit untuk menelusuri uang atau hasil kekayaan yang diperoleh dari korupsi;

2. Pelaku korupsi telah menghabiskan uang hasil atau mempergunakan/mengalihkan

dalam bentuk lain termasuk mengatasnamakan orang lain yang sulit terjangkau oleh hukum;

3. Adanya pihak ketiga yang menggugat pemerintah atas barang bukti dalam rangka pemenuhan pembayaran uang pengganti. $^{13}$

13 Efi Laila Kholis, Pembayaran Uang Pengganti Dalam Perkara Korupsi, Cetakan Pertama, Solusi Publishing, Jakarta, April 2010, hlm. 15. 
Problematika uang pengganti tidak berhenti sampai disana, setelah terpidana memilih menjalani pidana subsider putusan pidana penjara pengganti sebagai pengganti dari pidana uang pengganti yang disebutkan dalam putusan hakim tidak seimbang karena dalam praktek nilai uang pengganti yang jumlahnya ratusan sampai miliaran rupiah disubsiderkan dengan pidana penjara yang relatif singkat. Konstan putusan semacam ini menjadi keinginan setiap pelaku tindak pidana korupsi karena dengan kesalahan yang berat mereka hanya mengganti dengan beberapa bulan kurungan meskipun itu hanya sebagai tambahan seperti terlihat tabel di bawah ini:

Tabel .I.

Kesenjangan Uang Pengganti dengan Pidana Subsidernya

\begin{tabular}{|c|l|l|c|}
\hline No & \multicolumn{1}{|c|}{ Putusan } & \multicolumn{1}{|c|}{ Uang Pengganti } & Pidana Penjara Pengganti \\
\hline $\mathbf{1}$ & No 1087 K/Pid.Sus/2012 & Rp. 150.000 .000 & 5 bulan \\
\hline $\mathbf{2}$ & No 2360 K/Pid.Sus/2013 & Rp 155.000.000 & 15 bulan \\
\hline $\mathbf{3}$ & No 11K/Pid.Sus/2014 & Rp. 599.550.000 & 8 bulan \\
\hline $\mathbf{4}$ & No 1/K/Pid.Sus/2015 & Rp. 681.045.454 & 6 bulan \\
\hline $\mathbf{5}$ & MA : 1949K/Pid.Sus/2014 & Rp. 309.493.500, & 6 Bulan \\
\hline
\end{tabular}

Sumber : Sistem Informasi MA. Tahun 2015.

Data ini menunjukan bahwa dalam praktik pengembalian kerugian negara (asset recovery) tidak berjalan seperti yang menjadi harapan masyarakat luas, Undang-undang pemberantasan tindak pidana korupsi menghendaki adanya pengembalian kerugian negara bukan hanya melakukan penghukuman terhadap pelaku. Pelaku lebih memilih tidak melunasi uang pengganti atau lebih memilih menggantinya dengan pidana penjara pengganti (subsider). Putusan di atas juga menunjukan pola ketidaksebandingan dalam menentukan uang pengganti.
Perbuatan korupsi yang secara riil merugikan keuangan negara hanya diganti dengan pidana penjara di bwah 1 (satu) tahun. Negara mengalami kerugian ekonomi yang cukup memprihatinkan dan akibat tersebut dirasakan langsung oleh masyarakat tetapi kesalahan itu hanya ditebus dengan pidana kurungan yang cukup ringan. Model pemidanaan ini cukup melukai rasa keadilan masyarakat luas. Padahal semestinya uang pengganti sebagai pidana tambahan dalam tindak pidana korupsi bisa menjawab harapan masyarakat agat koruptor bisa mengembalikan uang negara. Pidana

\begin{tabular}{c} 
Copyright $\odot$ 2017, Jurnal Hukum Mimbar Justitia \\
Fakultas Hukum Universitas Suryakancana \\
Dinamika Pembayaran Uang Pengganti Dalam Tindak Pidana Korupsi \\
\hline
\end{tabular}


uang pengganti memberikan manfaat yang besar jika penegak hukum mampu mengembalikannya melalui pidana uang pengganti.

Pidana uang pengganti memang diformulasikan sebagai pidana tambahan, sifatnya fakultatif hanya menambah sanksi pidana pokok. Penjatuhan uang pengganti sangat bergantung pada kebijaksanaan hakim dalam menilai bukti-bukti yang muncul dalam persidangan. Hakim memiliki kemerdekaan untuk menjatuhkan uang pengganti pada terpidana atau tidak, tetapi jika dalam proses pembuktian Penuntut Umum mampu menunjukan adanya kerugian negara yang riil dan pasti jumlahnya akibat tindak pidana korupsi maka pidana pokok yang bersifat fakultatif bisa menjadi wajib dijatuhkan. Problemnya seperti telah disebutkan bahwa ketentuan Pasal 18 ayat (3) UU Pemberantasan Tindak Pidana Korupsi memberi ruang kepada hakim untuk mensubsiderkan yang berakibat pada lolosnya koruptor dari kewajiban membayar uang pengganti. Akibatnya negara tetap merugi dan korupsi indeks persepsi korupsi terus meningkat.
Barda Nawawi Arief bahwa strategi kebijakan pemidanaan dalam kejahatan-kejahatan yang berdimensi baru harus memperhatikan hakekat permasalahan. Bila hakekat permasalahannya lebih dekat dengan masalah-masalah di bidang hukum perekonomian maka lebih diutamakan penggunaan pidana denda atau semacamnya. Penetapan sanksi pidana seharusnya dilakukan melalui pendekatan rasional. Bila berdasar pada konsep rasional ini, maka kebijakan penetapan sanksi pidana tidak terlepas dari penetapan tujuan yang ingin dicapai oleh kebijakan kriminal secara keseluruhan, yakni perlindungan masyarakat. $^{14}$

Pengembalian kerugian negara mesti dilakukan berdasarkan kebijakan yang rasional dengan mempertimbangkan kondisi ekonomi terpidana yang tidak memungkinkan untuk melunasi pidana uang pengganti, sehingga dimungkinkan bagi hakim untuk menggantinya dengan pidana

14 Barda Nawawi Arief, Pembaruan Penegakan Hukum dengan Nilai-nilai Moral Religius, Makalah disampaikan pada Seminar Nasional Menembus Kebuntuan Legal Formal Menuju Pembangunan Hukum dengan Pendekatan Hukum Progresif, FH Undip 19 Desember 2009. hlm 13. 
penjara. Namun demikian kebijakan penetapan sanksi pidana penjara pengganti harus benar-benar seimbang dan proporsional dengan nilai uang pengganti yang dibebankan kepada terpidana dengan dasar perhitungan bahwa "semakin besar nilai kerugian negara akibat korupsi, semakin lama pidana pengganti yang harus dijalani”.

Dinamika pembayaran uang pengganti dalam kebijakan pelaksanaan sanksi pidana harus ditanggulangi dengan kebijakan pemidanaan yang rasional dan seimbang. ${ }^{15}$ Prinsip proporsionalitas perlu dijadikan landasan hakim dalam menentukan bobot lamanya pidana subsider uang pengganti, agar problem ketidaksebandingan antara jumlah uang pengganti dengan pidana subsider dapat dihindari karena prinsip proporsional menuntut adanya kesebandingan antara kesalahan dengan hukuman yang akan diterima.

15 Bandingkan Eva Achjani Zulfa, Pergeseran Paradigma Pemidanaan, Cetakan ke 1, Lubuk Agung, Bandung, 2011, hlm. 38.

\section{B. Strategi Penegakan Hukum Pidana Untuk Mengatasi Dinamika Pidana Uang Pengganti \\ Kebutuhan hukum dalam} pemberantasan korupsi saat ini adalah penegakan hukum yang berorientasi pada pengembalian kerugian negara yang dicuri dan dinikmati oleh koruptor. Korupsi yang terjadi di Indonesia tidak memiliki motivasi untuk bertahan hidup (corruption by need), melainkan didorong oleh gaya hidup yang tinggi (corruption by life style). Oleh karena itu penerapan sanksi pidananya perlu bergeser dari paradigma follow the person ke follow the money and asset.

Optimalisasi pidana uang pengganti memerlukan pendekatan hukum progresif untuk mengejar kerugian negara. Persoalannya adalah bagaimana melakukan langkan optimalisasi pidana uang pengganti melalui hukum progresif. Keberadaan hukum progresif memberikan tantangan bagi penegak hukum untuk melihat hukum sebagai suatu yang terus berproses karena hukum progresif tidak melihat hukum sebagai sesuatu yang mutlak dan final. 
Merujuk pada uraian sebelumnya dapat dilihat bahwa sebab utama dinamika pidana uang pengganti pada kenyataannya disebabkan karena faktor kebijakan formulasinya, disamping komitmen penegak hukum. Untuk optimalisasi pidana uang pengganti diperlukan perubahan atau penyempurnaan kebijakan dalam penanggulangan perkara korupsi diimbangi dengan cara berhukum progresif yang tidak terkungkung oleh positivisme hukum karena konsep hukum progresif selalu melihat hukum bukan suatu institusi yang mutlak dan final. ${ }^{16}$

Terobosan hukum optimalisasi pidana uang pengganti melalui penegakan hukum progresif bukanlah terobosan hukum yang bersifat emosional melainkan terobosan hukum yang rasional dan berlandaskan pada argumentasi teoritik. Landasan teoritis optimalisasi pidana uang pengganti adalah dengan menggunakan kacamata hukum progresif yang setia pada asas besar "hukum adalah untuk manusia bukan sebaliknya" sebagai pintu masuk

16 Bandingkan Achmad Rivai, Penemuan Hukum oleh Hakim, Dalam Perspektif Hukum Progresif, Sinar Grafika, Jakarta, 2014, hlm. 40. dan titik pandang (point of view). ${ }^{17}$ Hukum progresif melihat hukum selalu berada dalam proses untuk terus menerus menjadi (law as proces, law in the making) dan tidak memandang hukum dari kacamata hukum itu sendiri, tetapi dilihat dari tujuan sosial yang ingin dicapai. ${ }^{18}$

Optimalisasi

pengembalian kerugian negara dengan uang pengganti melalui penegakan hukum progresif menekankan pada aspek manusianya (penegak hukum). Untuk memperlancar arus pengembalian uang negara, maka penegak hukum perlu berhukum secara progresif dengan melaksanakan ketentuan penyitaan sebagaimana diatur dalam Pasal 18 ayat (2) UndangUndang Nomor 31 Tahun 1999 Tentang Pemberantasan Tindak Pidana Korupsi dari yang semula dapat dilaksanakan jika uang pengganti tidak dibayar, menjadi dapat dilaksanakan sejak tahap penyidikan. Tindakan ini sebagai terobosan hukum (rule breaking) untuk mengantisipasi agar harta yang menjadi

17 Dey Ravena, Wacana Konsep Hukum Progresif Dalam Peegakan Hukum di Indonesia Dalam Hukum Untuk Manusia Kado (tak) Istimewa Fakultas Hukum Untuk Indonesia, Pilar Utama Mandiri, Jakarta, 2012, hlm. 338.

18 Satjipto Rahardjo, Membedah Hukum Progresif, Kompas, Jakarta, 2007, hlm. 162. 
Ade Mahmud

Jurnal Hukum Mimbar Justitia

Vol. 3 No. 2 - Desember 2017

obyek uang pengganti tidak dialihkan dan memudahkan pelacakan, sehingga mempermudah jaksa untuk memohon sita jaminan. Masalah sita jaminan ini pernah diadopsi dalam putusan kasasi No 2190/K/Pid.Sus/2010. Dalam putusan tersebut majelis hakim menetapkan bahwa sebuah rumah yang tidak terkait dengan perkara, dijadikan sebagai jaminan pembayaran uang pengganti. Pertimbangan tersebut menurut penulis diambil majelis hakim dengan merujuk pada Pasal 1131 Kitab Undang-undang Hukum Perdata yang menetapkan bahwa:

"Segala barang-barang bergerak dan tidak bergerak milik debitur, baik yang sudah ada maupun yang baru akan ada menjadi jaminan untuk perikatan-perikatan perorangan debitur itu”.

Dalam perkara ini terpidana dianalogikan sebagai debitur dan uang pengganti dianalogikan sebagai prestasi dalam perikatan yang harus dipenuhi terpidana, sedangkan negara (korban) dianalogikan sebagai kreditur konkuren. Hal ini menimbulkan konsekuensi bahwa harta benda terpidana baik yang sudah ada maupun yang akan ada menjadi jaminan pelunasan pembayaran uang pengganti. Putusan ini merupakan terobosan untuk mengefektifkan pembayaran uang pengganti sekaligus menegaskan bahwa Mahkamah Agung mengakui konsep sita jaminan dalam perkara korupsi sebagai instrumen untuk menjamin terlaksananya eksekusi pidana uang pengganti. Praktik ini menunjukan Mahkamah Agung melalui putusan di atas menerima sita jaminan sebagai jaminan pelunasan uang pengganti tanpa perlu menunggu lunasnya uang pengganti, namun untuk menghindari adanya perlawanan dari pihak ketiga maka sita jaminan perlu dikuatkan sedini mungkin dalam taraf kebijakan (UU Tipikor) yaitu sejak tahap penyidikan.

Untuk melakukan tindakan tersebut hakim harus berani melakukan analogi, meskipun dengan diterimanya asas legalitas dalam hukum pidana nasional dengan sendirinya mengandung asas non-retroactivity tidak bersifat retrospective, dan menolak analogi, tapi tidak menutup pintu untuk melakukan penafsiran yang lebih luas (extensif). Hakim seharusnya bukanlah corong undang-undang (la bouche de la loi) belaka, tetapi sebagai ujung tombak penegak hukum hakim dapat melakukan penemuan hukum 
melalui putusan-putusannya. Dengan metode interpretasi dan kontruksi hukum, tetapi sejauh mungkin hakim tidak menggunakan analogi dalam menjatuhkan putusan, karena analogi dilarang dalam hukum pidana yang menganut asas legalitas. Meskipun analogi dilarang penggunaannya dalam hukum pidana, tidak berarti tertutup kemungkinan bagi hakim untuk menyimpanginya, sebab hakim adalah aktor yang memiliki kebebasan untuk memilih alternatif tindakan yang tepat dalam mencapai rasa keadilan bagi masyarakat.

Walaupun metode analogi dilarang penggunaannya oleh hakim tetapi menurut doktrin, ada dua (2) teori yang dapat digunakan oleh hakim apabila akan menerobos larangan tersebut, yaitu: ${ }^{19}$

\section{Teori Voluntarism Talcot Parson}

Menurut teori ini hakim dapat memilih penggunaan analogi tersebut, dengan konsep voluntarism, yaitu kemampuan individu melakukan tindakan dalam arti menetapkan cara atau alat sebagai alternatif tersedia dalam rangka mencapai tujuan. Aktor

19 Antonius Sudirman, Hati Nurani Hakim dan Putusannya, PT Citra Aditya Bakti, Bandung, 2007, hlm. 72. menurut konsep voluntarism ini adalah perilaku aktif dan kreatif serta mempunyai kemampuan untuk menilai dan memilih dari alternatif yang ada. Dengan demikian, hakim sebagai aktor dapat bertindak kreatif untuk mencapai putusan yang memberikan rasa keadilan.

2. Teori Psikologi Humanistik

\section{Abraham Maslow}

Menurut teori ini manusia adalah mahluk yang bebas dalam menentukan tujuannya. Potensi kreatif merupakan potensi yang umum pada manusia. Dalam hal ini hakim adalah mahluk bebas yang dapat menentukan tindakan atau putusannya melalui diskretonary of judiciary.

\section{Menurut Purnadi Purbacaraka} dan Soerjono Soekanto bahwa hakim mempunyai diskresi bebas, perasaannya tentang apa yang benar dan apa yang salah merupakan pengarahan sesungguhnya untuk mencapai keadilan. Ajaran hukum bebas (freirechtslehre) memberikan kepada hakim kehendak bebas dalam pengambilan keputusan. ${ }^{20}$

20 Bandingkan Renny Supriyatni, Penerapan Fiqih Muamalah Sebagai Dasar Kewenangan Pengadilan Agama Dalam Penyelesaian Sengketa Ekonomi Syariah, Jurnal Syiar Hukum, Vol. XII, No. 3, November 2010, hlm. 199. 
Hakim dapat menentukan keputusannya tanpa harus terikat pada undangundang. ${ }^{21}$ Indonesia menganut ajaran hukum bebas, sehingga hakim diberikan kebebasan untuk menggali nilai-nilai hukum yang hidup di kalangan rakyat untuk diisi dalam putusannya. ${ }^{22}$

Teori yang dapat digunakan untuk menjelaskan perilaku penyimpangan hakim terhadap asas fundamental dalam hukum pidana (asas legalitas) itu adalah teori penyimpangan (deviant theory), sebagaimana dikemukakan oleh $\mathbf{R}$ Seidman. Teori ini dikenal juga dengan teori pengaruh kekuatan sosial dan personal bekerjanya hukum dalam masyarakat. Dalam teori tersebut terdapat tiga komponen utama pendukung bekerjanya hukum dalam masyarakat, yaitu:

1. Lembaga pembuat peraturan;

2. Lembaga penerap peraturan; dan

3. Pemegang peran. ${ }^{23}$

Menurut teori ini para pemegang peran (role occupant) dapat mempunyai

21 Bandingkan Haryanto Dwiatmodjo, Penjatuhan Pidana Bersyarat Dalam Kasus Pencurian Kakao, Jurnal Yudisial, Vol. V, No. 01, April 2012, hlm. 111.

22 Purnadi Purbacaraka dan Soerjono Soekanto, Renungan tentang Filsafat Hukum, Rajawali Press, Jakarta, 1985, hlm. 37.

23 Dey Ravena, Op. Cit, hlm. 342. motivasi baik berkehendak untuk menyesuaikan diri dengan norma (conform of norm) maupun yang berkehendak untuk tidak menyesuaikan diri dengan keharusan norma (non conform of norm) sebagai respon terhadap peraturan hukum yang ditujukan kepadanya, sanksi-sanksinya, aktivitas dari lembaga-lembaga pelaksana serta keseluruhan kompleks kekuatan sosial, politik dan lainlainnya. $^{24}$

Hakim sebagai aktor yang memiliki kebebasan dalam menentukan tindakan apa yang dilakukannya untuk memberikan keadilan subtantif, ${ }^{25}$ maka sesungguhnya dalam konteks optimalisasi pidana uang pengganti hakim dapat memainkan peran politik tertentu yang ingin dicapai melalui putusan-putusannya. Akan tetapi, peran

${ }^{24}$ Teori ini dikenal pula dengan teori kekuatan sosial dan personal yang memberitahu bagaimana seorang pemegang peran (role occupant) dan lembaga-lembaga pelaksana itu akan bertindak sebagai respon terhadap peraturan hukum yang ditujukan kepada mereka, sanksi-sanksinya, keseluruhan kompleks kekuatan sosial, politik dan kekuatan lain-lainnya yang mengenai diri mereka serta umpan balik yang datang dari pemegang peranan

25 Ridwan, Mewujudkan Karakter Hukum Progresif dari Asas-asas Umum Pemerintahan yang baik Soluasi Penemuan Keadilan Subtantif, Jurnal Hukum Projustitia, Vo.l 26, No. 2, 2008, hlm. 170. 
Ade Mahmud

Jurnal Hukum Mimbar Justitia

Vol. 3 No. 2 - Desember 2017

politik yang dimainkan oleh hakim bukan politic judicial restraint yang hanya menjalankan politik patuh pada undang-undang, melainkan politic judicial activism yang mengandung makna bahwa dalam menjatuhkan putusannya, hakim dapat mengadakan pilihan dari berbagai alternatif tindakan yang tepat untuk tercapainya rasa keadilan dalam masyarakat. Untuk itu dalam pandangan Satjipto Rahardjo, sebaiknya pengadilan mengikuti political judicial activism, untuk membuat putusan-putusan yang bernilai monumental agar mampu mengembalikan kerugian negara untuk membangun bangsa ini, sehingga pengadilan dapat menjadi motor penggerak melalui putusanputusannya. $^{26}$

Dengan strategi terobosan hukum (rule breaking) berupa penyitaan sejak tahap penyidikan tanpa melihat apakah aset tersebut ada kaitannya atau tidak dengan tindak pidana korupsi diharapkan dinamika uang pengganti dapat diatasi melalui kanal penegakan hukum progresif. Karena tidak mungkin hakim menjatuhkan pidana tanpa subsider kepada pelaku yang benar-

${ }^{26}$ Antonius Sudirman, Op. Cit, hlm. 43. benar tidak memiliki harta yang cukup untuk membayarnya. Konsep sita jaminan dalam hukum pidana memungkinkan dilaksanakan karena beberapa putusan di tingkat Mahkamah Agung pernah menerapkan pola tersebut.

Kebijakan sita jaminan bukan bermaksud untuk melakukan pemiskinan terhadap pelaku tindak pidana korupsi karena pidana tidak boleh mengandung unsur over penalization tetapi semata-mata hanya untuk menjadi jaminan agar pelaku membayar pidana uang pengganti yang dijatuhkan dalam putusan pengadilan. Konsep sita jaminan cukup berguna untuk meminimalisasi dinamika pembayaran uang pengganti yang tidak dibayar atau hanya dibayar sebagian.

\section{PENUTUP}

A. Kesimpulan

1. Pelaksanaan pembayaran pidana uang pengganti mengalami dinamika yang kompleksitas karena aturan pidana tambahan dalam Undang-Undang Nomor 31 Tahun 1999

Tentang Pemberantasan Tindak Pidana Korupsi memberikan ruang bagi 
hakim untuk mensubsiderkan pidana uang pengganti dengan pidana penjara yang relatif singkat. Realitas empiris menunjukan terjadi kecendeurngan terpidana korupsi untuk memilih menjalani pidana subsider dibandingkan membayar uang pengganti karena bobot pidana subsider jauh lebih ringan dan cukup ekonomis daripada harus mengganti kerugian negara sehingga negara secara ekonomi tetap merugi dan indeks persepsi korupsi terus mengalami peningkatan.

2. Strategi penegakan hukum pidana untuk mengatasi dinamika pidana uang pengganti adalah menerapkan konsep hukum progresif yang setia pada asas besar "hukum untuk manusia" Konkritisasi hukum progresif dalam strategi mengatasi problem uang pengganti dilaksanakan dengan melakukan upaya terobosan hukum (rule breaking) berupa sita jaminan terhadap aset milik pelaku tanpa melihat status aset berkaitan atau tidak dengan tindak pidana korupsi. Upaya sita jaminan dilakukan semata-mata hanya untuk mengantisipasi agar harta yang akan menjadi obyek uang pengganti tidak beralih kepada pihak lain dan memudahkan jaksa untuk melakukan eksekusi manakala hakim menjatuhkan pidana uang pengganti kepada terdakwa.

\section{B. Saran}

1. Dinamika pembayaran uang pengganti menunjukan realitas ketidakadilan dalam kebijakan penerapan sanksi pidana. Untuk itu disarankan kepada hakim agar mempertimbangkan aspek keseimbangan/kesebandingan antara pidana uang pengganti yang harus dibayar dengan pidana subsider yang dijalani sehingga terpidana yang tidak membayar uang pengganti wajib menjalani pidana subsider (penjara) yang seimbang (proporsional).

2. Langkah konkrit optimalisasi kebijakan penerapan sanksi pidana uang pengganti sebaiknya diserahkan sepenuhnya kepada penegak hukum untuk melakukan penegakan hukum progresif 
dengan melaksanakan konsep sita jaminan sejak tahap penyidikan untuk mengantisipasi aset yang menjadi obyek uang pengganti dapat dieksekusi jaksa pada saat terpidana tidak membayar uang pengganti. Dengan langkah tersebut kerugian keuangan negara akibat korupsi dapat dikembalikan secara utuh.

\section{DAFTAR PUSTAKA.}

\section{A. Buku.}

Achmad Rivai, Penemuan Hukum oleh Hakim, Dalam Perspektif Hukum Progresif, Sinar Grafika, Jakarta, 2014.

Antonius Sudirman, Hati Nurani Hakim dan Putusannya, PT Citra Aditya Bakti, Bandung, 2007.

Chaerudin dkk, Strategi Pencegahan dan Penegakan Hukum Tindak Pidana Korupsi, Reflika Aditama, Bandung, 2008.

Dey Ravena, Wacana Konsep Hukum Progresif Dalam Peegakan Hukum di Indonesia Dalam Hukum Untuk Manusia Kado (tak) Istimewa Fakultas Hukum Untuk Indonesia, Pilar Utama Mandiri, Jakarta, 2012.

Efi Laila Kholis, Pembayaran Uang Pengganti Dalam Perkara
Korupsi, Cetakan Pertama, Solusi Publishing, Jakarta, April 2010

Eva Achjani Zulfa, Pergeseran Paradigma Pemidanaan, Cetakan ke 1, Lubuk Agung, Bandung, 2011.

Iswan Kaputra dkk, Dampak Otonomi Daerah di Indonesia, Yayasan Obor Indonesia, Jakarta, 2013.

Marwan Mas, Pemberantasan Tindak Pidana Korupsi, Ghalia Indonesia, Bogor, 2015.

Satjipto Rahardjo, Membedah Hukum Progresif, Kompas, Jakarta, 2007.

Yesmil Anwar, Pembaharuan Hukum Pidana, PT Gramedia Widiasarana Indonesia, Jakarta, 2008.

\section{B. Peraturan undangan.}

Undang-Undang Nomor 1 Tahun 1946 Tentang Kitab Undang-undang Hukum Pidana.

Kitab Undang-undang Hukum Perdata.

Undang-Undang Nomor 31 Tahun 1999 Jo 20 Tahun 2001 Tentang Pemberantasan Tindak Pidana Korupsi.

\section{Jurnal, Makalah, Internet dan} Lain-lain.

Ade Paul Lukas, Efektivitas Pidana Pembayaran Uang Pegganti Dalam Tindak Pidana Korupsi, Jurnal Dinamika Hukum, 
Ade Mahmud

Jurnal Hukum Mimbar Justitia

Vol. 3 No. 2 - Desember 2017

Fakultas Hukum Universitas

Jenderal Soedirman, Vol. 10, No. 2, Mei 2010.

Barda Nawawi Arief, Pembaruan Penegakan Hukum dengan Nilainilai Moral Religius, Makalah disampaikan pada Seminar Nasional Menembus Kebuntuan Legal Formal Menuju Pembangunan Hukum dengan Pendekatan Hukum Progresif, FH Undip 19 Desember 2009.

Fontian Munzil, dkk, Kesebandingan Pidana Uang Pengganti dan Pengganti Pidana Uang Pengganti Dalam Rangka Melindungi Hak Ekonomi Negara dan Kepastian Hukum, Jurnal Hukum Ius Quia Iustum, Vol. 22, No. 1, Januari 2015.

Renny Supriyatni, Penerapan Fiqih Muamalah Sebagai Dasar Kewenangan Pengadilan Agama Dalam Penyelesaian Sengketa Ekonomi Syariah, Jurnal Syiar Hukum, Vol. XII, No. 3, November 2010 .

Ridwan, Mewujudkan Karakter Hukum Progresif dari Asas-asas Umum Pemerintahan yang baik Soluasi Penemuan Keadilan Subtantif, Jurnal Hukum Projustitia, Vo.l 26, No. 2, 2008.

Eva Mazrieva, Indeks Perspesi Korupsi Indonesia htts//voaindonesia.com. diakses Tgl 25 Oktober 2017. Pkl 13.00

Korupsi Dana Kesbangpol, Syarif Muda Dijatuhi Hukuman 14 bulan
Warmanplaw.blogspot.co.id. diakses tgl 1 April 2015. Pkl 14.00 